\title{
ULTRASTRUCTURAL CHANGES IN THE SARCOPLASMIC RETICULUM IN ACUTE MYOCARDIAL ISCHEMIA
}

\author{
Kazuhide Akiyama, M.D., Noburu Konno, M.D., Toshikuni Yanagishita, M.D. \\ Fumihiro TANno, M.D., and TAKashi Katagiri, M.D.
}

\begin{abstract}
We investigated the morphologic changes in the sarcoplasmic reticulum (SR) in acute myocardial ischemia, induced by occlusion of the coronary artery in the canine heart, by freeze-fracture of SR in situ and in vitro, and they were compared to the alterations in $\mathrm{Ca}^{++}$-stimulated ATPase activity and protein composition of the isolated SR. Both SR in situ and the isolated SR exhibited typical intramembranous particles with diameters of 70 to $90 \AA$ in freeze-fracture replicas. The intramembranous particle density of the $\mathrm{P}$ face in SR in situ was 3,319 \pm 75 (mean $\pm \mathrm{SE}$ ) per $\mu \mathrm{m}^{2}$ and that in the isolated SR was 2,667 \pm 60 ; particles were more numerous on the concave (P) face than on the convex (E) face. In ischemia for 30 to 60 min a significant decrease in the number of particles was found in SR in situ, and the corresponding change was noted in the isolated SR. Simultaneous decreases in $\mathrm{Ca}^{+}$-stimulated ATPase activity and the major ATPase protein of the SR were recognized. The close correlation of the changing pattern between the reduction in $\mathrm{Ca}^{++}$. ATPase and that in intramembranous particle density during ischemia supports the suggestion that a large part of the intramembranous particles represent ATPase protein itself. Decrease in the SR membrane particles strongly suggests the degradation of ATPase protein in the process of ischemic myocardial injury.
\end{abstract}

$\mathbf{T}$ HE sarcoplasmic reticulum (SR) is a highly specialized membrane system which regulates calcium ion fluxes during contraction and relaxation. The ATP-dependent calcium pump of the SR membrane establishes a consentration gradient for $\mathrm{Ca}^{*}$ across this membrane. Although many biochemical data indicate decreases in $\mathrm{Ca}^{++}$. ATPase activity and $\mathrm{Ca}^{\text {+ }}$-binding rate of the $\mathrm{SR}$ after acute coronary artery occlusion, ${ }^{1-3}$ their membrane structures appear to be relatively unchanged on ultrathin sections in transmission

\section{Key Words:}

Sarcoplasmic reticulum

Myocardial ischemia

Freeze-fracture

$\mathrm{Ca}^{++}$-ATPase activity

Canine heart electron microscopy, showing, for example, mere swelling.,5 The freeze-fracture technique was introduced in order to characterize the alteration in membrane interiors during ischemic injury in correlation with the chronologic biochemical changes in the SR.

From gel electrophoretic analysis of the SR proteins, the $\mathrm{Ca}^{+}$-pump ATPase protein constitutes 40 to $50 \%$ of the proteins of the SR membrane and its molecular weight is about 100,0006,7 This ATPase is an intrinsic component of the SR, presumably located in the lipid phase of the membrane, and has been characterized ultrastructurally by freeze-fracture technique to be 70 to $90 \AA$ particles of the $P$ face of the fractured skeletal ${ }^{8}$ and cardiac $^{9}$ SR membranes. In this article we estimated changes

(Received September 18, 1985; accepted March 20, 1986)

The Third Department of Internal Medicine, Showa University School of Medicine, Tokyo, Japan

Mailing address: Kazuhide Akiyama, M.D., The Third Department of Internal Medicine, Showa University School of Medicine, 1-5-8 Hatanodai, Shinagawa-ku, Tokyo 142, Japan 
in the density of the intramembranous particles (IMP) of 70 to $90 \AA$ in diameter in the freezefractured SR membrane and correlated them with alterations in $\mathrm{Ca}^{++}$-stimulated ATPase activity and composition of SR proteins of the isolated SR in experimental ischemic myocardium in the dog.

\section{MATERIALS AND METHODS}

Surgical procedure. Twenty-six adult mongrel dogs, weighing 10 to $22 \mathrm{~kg}$, were anesthetized with intravenous injection of sodium pentobarbital $\left(\mathrm{Nembta}^{\circledR}\right)$ at $30 \mathrm{mg} / \mathrm{kg}$ body weight. A left-sided thoracotomy was performed under positive pressure respiration with room air using a Harvard type respirator. The anterior descending branch of the left coronary artery was isolated and ligated completely with a silk thread just below the first diagonal branch. The occurrence of transmural myocardial ischemia was confirmed by a continuous ST segment elevation of more than $0.5 \mathrm{mV}$ in the leads near $\mathrm{V}_{3}$ and $\mathrm{V}_{4}$. The dogs were sacrificed chronologically from 30 to $180 \mathrm{~min}$ after ligation and the heart was removed in the beating state. The subendocardial muscle at the central portion of the postischemic cyanotic region was excised immediately, with the non-ischemic portion of the left ventricle as a control.

Freeze-fracture technique. Myocardial tissue was cut into small blocks in $2 \%$ glutaraldehyde containing $7.5 \%$ sucrose buffered with $0.1 \mathrm{M}$ cacodylate $\mathrm{HCl}$ (pH 7.2). Subsequently the blocks were fixed in the same solution for 2 hours and transferred to $0.1 \mathrm{M}$ cacodylate (pH 7.2) containing 30\% glycerol for 2 hours at $4^{\circ} \mathrm{C}$. Small cubes of tissue were fitted in the tissue holders and immediately frozen in Freon 22 which was cooled with liquid nitrogen. The frozen tissues were transferred to the cold stage of an Eiko-FD-2A unit and fractured at $-115^{\circ} \mathrm{C}$, in a vacuume of $2 \times 10^{-7}$ Torr. Fractured surfaces were immediately shadowed with platinum at an angle of $45^{\circ}$. The platinum replica was stabilized by deposition of pure carbon. The replicas were cleaned with bleach, rinsed in distilled water and mounted on uncoated copper grids.

Pelleted fractions of isolated microsomal vesicles were incubated in $30 \%$ glycerol with $0.1 \mathrm{M}$ cacodylate buffer overnight to allow gentle resuspension of the pellet. Small droplets were placed on the tissue holders and frozen as described above.

Stereological procedure. The replicas were photographed in an electron microscope (Hitachi $\mathrm{H}-300$ ) at 30,000 fold. The negatives were projected on film for counting (final magnification, $\times 150,000)$. A $8 \mathrm{~mm}$ test circle was placed randomly on the $\mathrm{P}$ and $\mathrm{E}$ face of intact $\mathrm{SR}$ membrane. The number of 70 to $90 \AA$ particles enclosed by the circle was counted. The $8 \mathrm{~mm}$ test circle corresponded to an area of $2.2 \times 10^{-3}$ $\mu \mathrm{m}^{2}$. For the isolated SR vesicles, the same $8 \mathrm{~mm}$ circle was placed on concave and convex profiles free of cast shadow! ${ }^{10}$ All the IMP totally enclosed within the circle were counted. For intact myocardium, 100 circles (area: $0.22 \mu \mathrm{m}^{2}$ ) were counted on the SR membrane. In the isolated SR 200 vesicles were counted at each stage of ischemia (area: $0.44 \mu \mathrm{m}^{2}$ ).

Preparation of the sarcoplasmic reticulum. Isolation of the SR was performed by the modified method of Harigaya and Schwartz, ${ }^{11}$ as described previously! All the procedures were done at $4^{\circ} \mathrm{C}$ unless otherwise mentioned. Briefly, approximately $2 \mathrm{Gm}$ of myocardial tissue were cut into small pieces and homogenized in $9 \mathrm{vol}$ of a solution containing $0.01 \mathrm{M} \mathrm{NaHCO}{ }_{3}, 0.005$ $\mathrm{M} \mathrm{NaN}_{3}$ and $0.0001 \mathrm{M}$ EGTA with a Polytron homogenizer PT-3J 3 times for $5 \mathrm{sec}$ with intervals of $20 \mathrm{sec}$. The homogenate was spun at $9000 \times \mathrm{G}$ for $10 \mathrm{~min}$ twice, and the supernatant was centrifuged at $120,000 \times \mathrm{G}$ for $30 \mathrm{~min}$. The final pellet was suspended in $0.05 \mathrm{M} \mathrm{KCl}$ and $0.02 \mathrm{M}$ tris (h-ydroxymethyl) methylaminoethanesulfonic acid (TES)-tris (pH 7.0), the suspension was ultracentrifuged again, and the precipitate was saved as the SR fraction. Protein concentration was determined by the method of Lowry using $1 \mathrm{mg} / \mathrm{ml}$ bovine serum albumin in $0.05 \mathrm{M} \mathrm{KCl}$ and $0.02 \mathrm{M}$ TES-tris $(\mathrm{pH} \mathrm{7.0)}$ as a standard.

Measurement of ATPase activity. $\mathrm{Ca}^{++}$stimulated ATPase activity of the isolated SR was examined by the modified method of Harigaya et al. ${ }^{12}$ ATPase reaction was performed in a medium containing $0.1 \mathrm{M} \mathrm{KCl}, 0.005 \mathrm{M}$ $\mathrm{MgCl}_{2}, 0.005 \mathrm{M} \mathrm{NaN}, 0.005 \mathrm{M} \mathrm{ATP}$ and $0.02 \mathrm{M}$ tris-maleate $(\mathrm{pH} 7.2)$ in the presence of $2 \times 0.00001 \mathrm{M} \mathrm{CaCl}_{2}$ or $0.001 \mathrm{M}$ EGTA. Reaction was started with the addition of ATP at $37^{\circ} \mathrm{C}$ for $5 \mathrm{~min}$ and stopped by the addition of 20\% TCA. The inorganic phosphate liberated from ATP was determined by the method of Fiske and SubbaRow! ${ }^{13}$

Sodium dodecyl sulfate polyacrylamide gel 


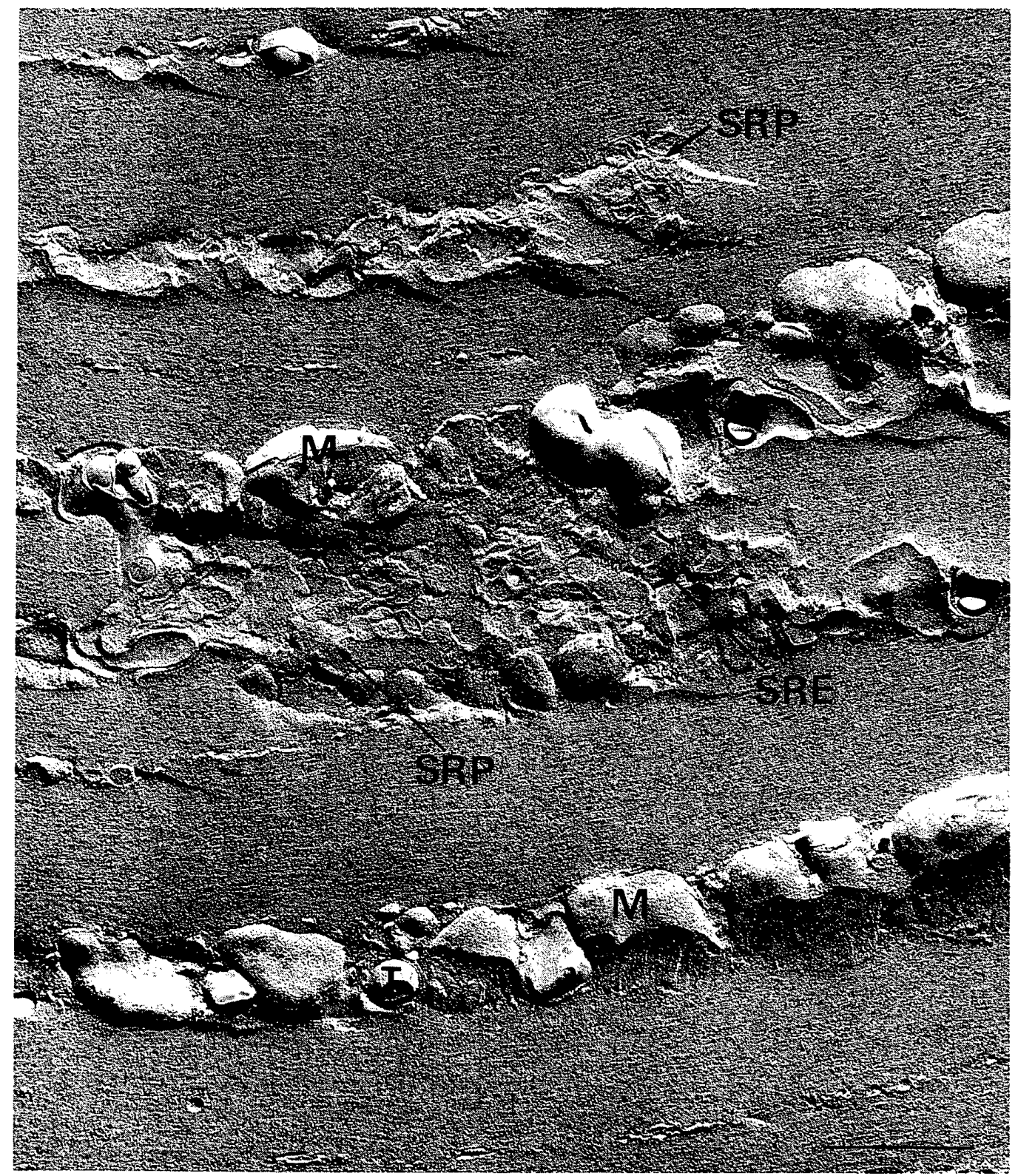

Fig.1. Freeze-fracture electron micrograph of a normal myocardial cell. Free sarcoplasmic reticulum (SR) shows a network of tubules and cisternae surrounding myofibrils. $S R P=P$ face of sarcoplasmic reticulum. $S R E=E$ face of sarcoplasmic reticulum. $M=$ mitochondria. $T=T$-system. Ber indicates $1 \mu \mathrm{m}$.

electrophoresis. SDS gel electrophoretic analysis of SR proteins was performed by the modified method of Weber and Osborn.14 Electrophoresis was done in cylindrical gels with a diameter of $5 \mathrm{~mm}$ and at a constant current of $8 \mathrm{~mA}$ per gel for $5 \mathrm{~cm}$. Gels were stained with coomassie brilliant blue. Composition of proteins was calculated from the densitometric curves.

\section{RESULTS}

Whole muscle fracture faces. In the normal myocardial cell the SR was recognized relatively easily in freeze-fracture replicas by its characteristic high density of IMP on the $P$ fracture face. The free SR presented a membranous intracellular network of tubules and cisternae surrounding myofibrils, as shown in Fig. 1. Generally, the junctional and free SR consisted of tubules with widths of between 20 to $60 \mathrm{~nm}$ as described by Sommer. ${ }^{15}$ Fig. $2 \mathrm{~A}$ shows the junctional SR wrapped around a T-tubule. The fracture plane sometimes exposed a large area of the SR membrane, flat enough for IMP counting. Fig. 2B shows several of the flat cisternae that are smoothly connected to tubules of the SR. 

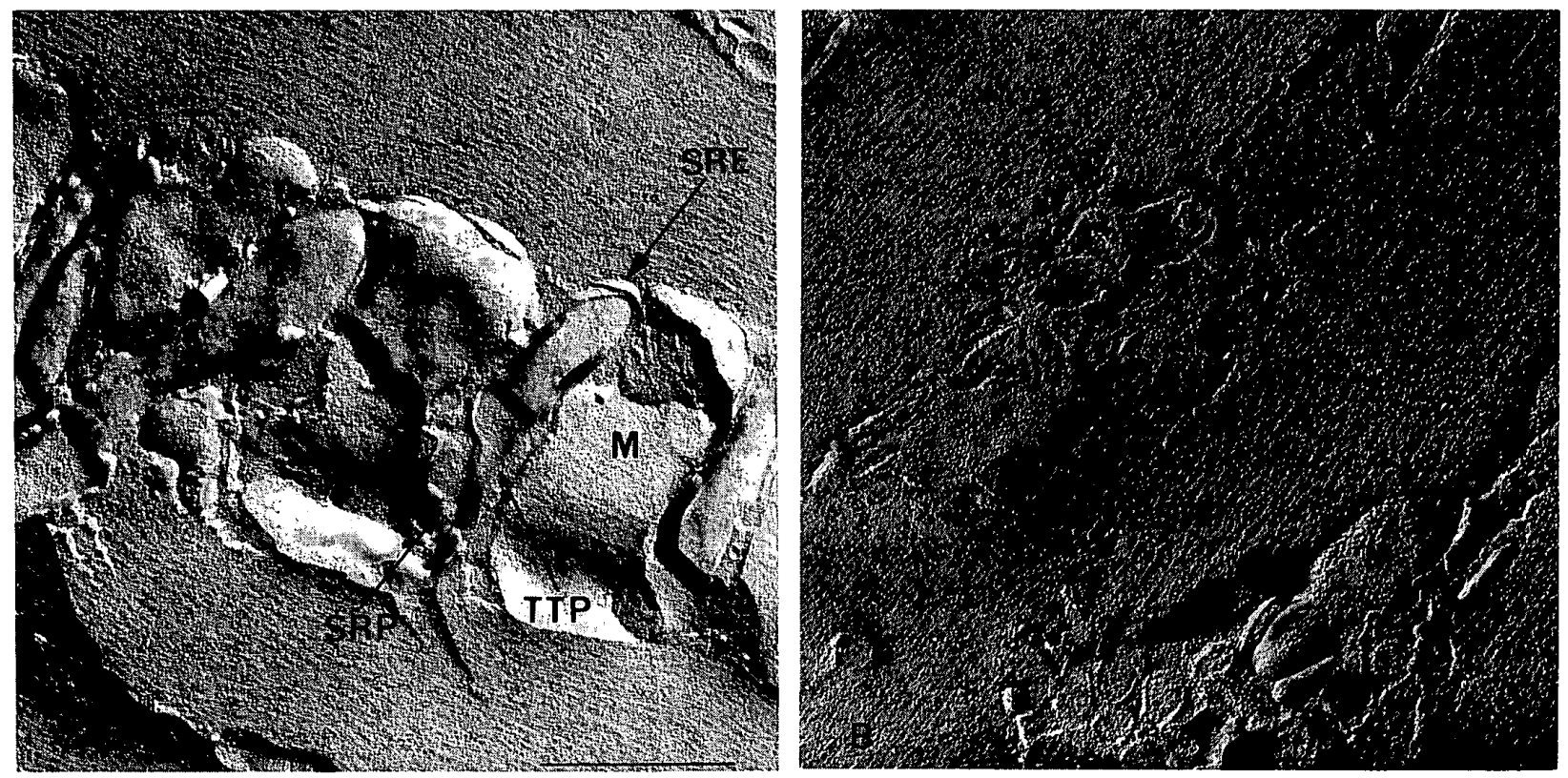

Fig.2. Freeze-fractured normal myocardial cells. A: P (SRP) and E (SRE) faces of the SR membrane and T-tubular membrane are shown. Compared to $P$ face of T-tubular membrane (TTP), the SR membrane has a much higher IMP density on its P face. B: Free SR shows flat cisternae smoothly connected to tubules of SR. A tubule of SR lies near mitochondria (arrow). SRP $=P$ face of sarcoplasmic reticulum. $\mathrm{SRE}=\mathrm{E}$ face of sarcoplasmic reticulum. $\mathrm{M}=$ mitochondria. $\mathrm{T}=\mathrm{T}-$ system. Bar indicated $1 \mu \mathrm{m}$.
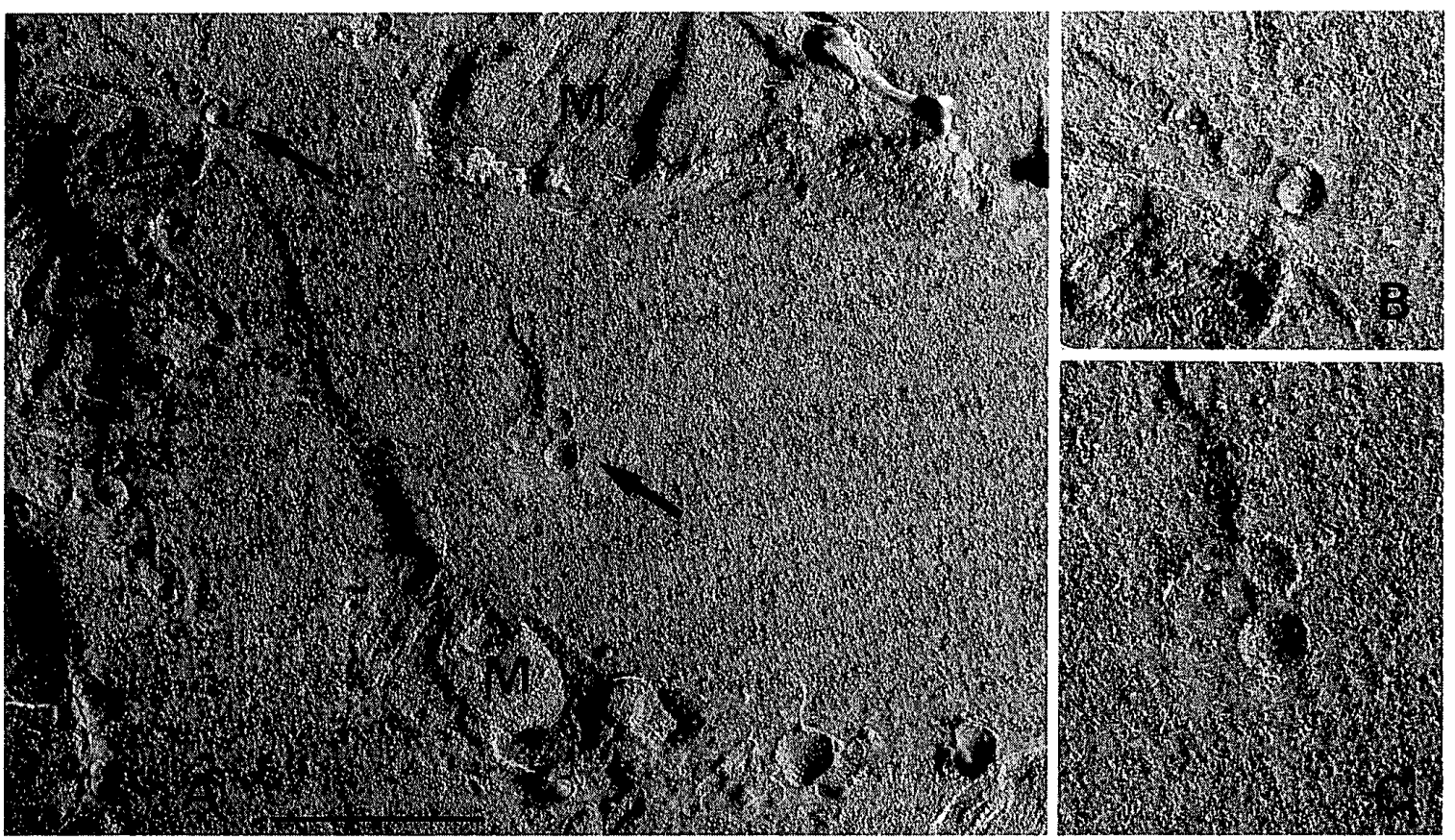

Fig.3. Ischemic myocardial cell at $30 \mathrm{~min}$ after coronary ligation. A: SR is slightly swollen and a reduction in the number of particles is noted on $P$ face of $S R$ (arrows). B,C: P face of SR. M = mitochondria. Bar indicates $1 \mu \mathrm{m}$.

In situ, the density of IMP on the $P$ face was counted as $3,319 / \mu \mathrm{m}^{2}$ on the average.

At $30 \mathrm{~min}$ after coronary ligation, the SR was swollen and a slight swelling of mitochondria was observed. The densities of IMP on the SR membrane decreased slightly, as shown in Fig. 3. Sixty to $180 \mathrm{~min}$ after coronary ligation, marked intracellular edema was observed and swelling of 


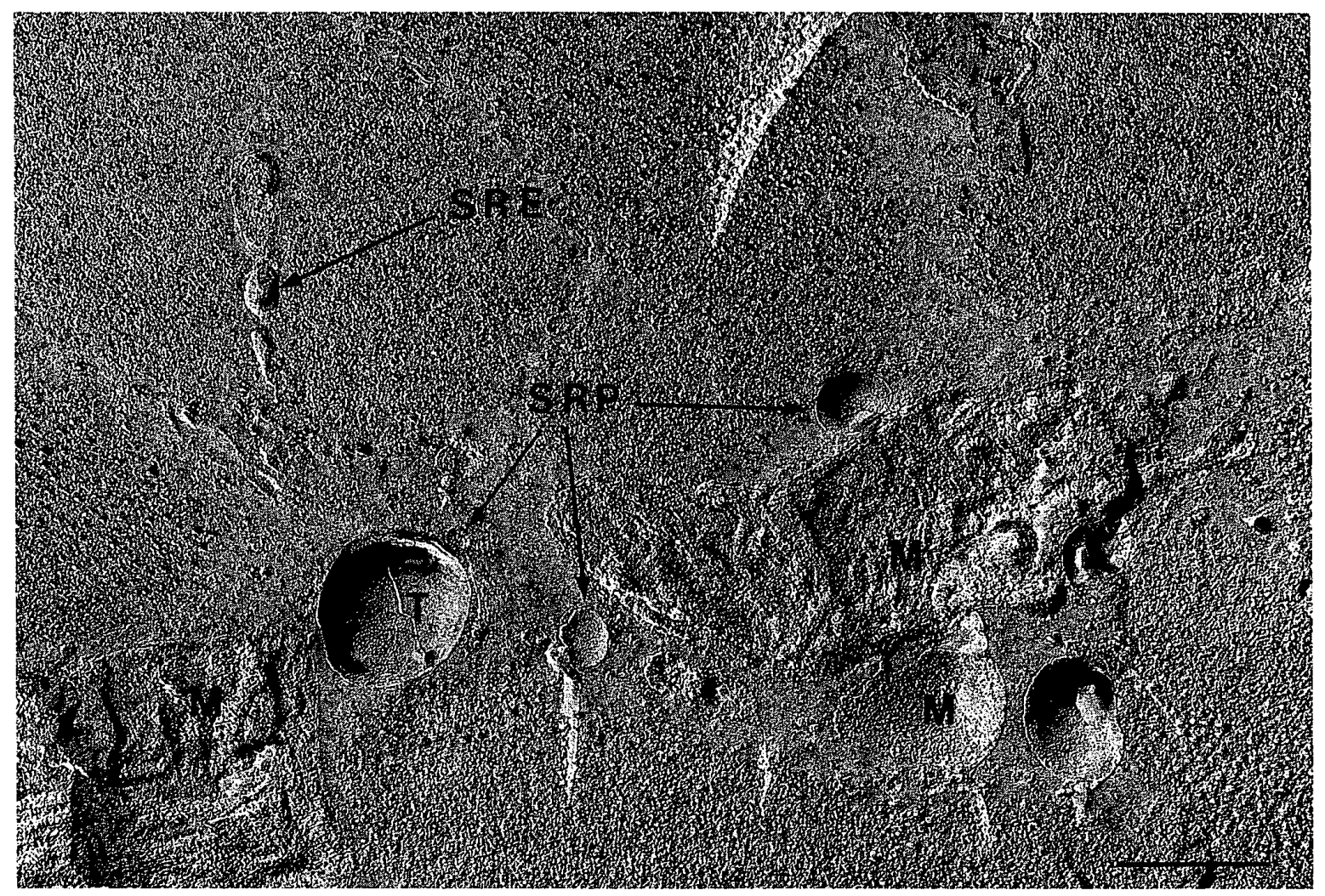

Fig.4. A myocardial cell $60 \mathrm{~min}$ after coronary ligation. Sarcoplasmic reticulum appears vesiculated, and there is a decrease in particle density on $P$ face of sarcoplasmic reticulum (SRP). $\mathrm{SRE}=\mathrm{E}$ face of sarcoplasmic reticulum. $\mathbf{M}=$ mitochondria. $\mathrm{T}=\mathrm{T}$-system. Bar indicates $0.5 \mu \mathrm{m}$.

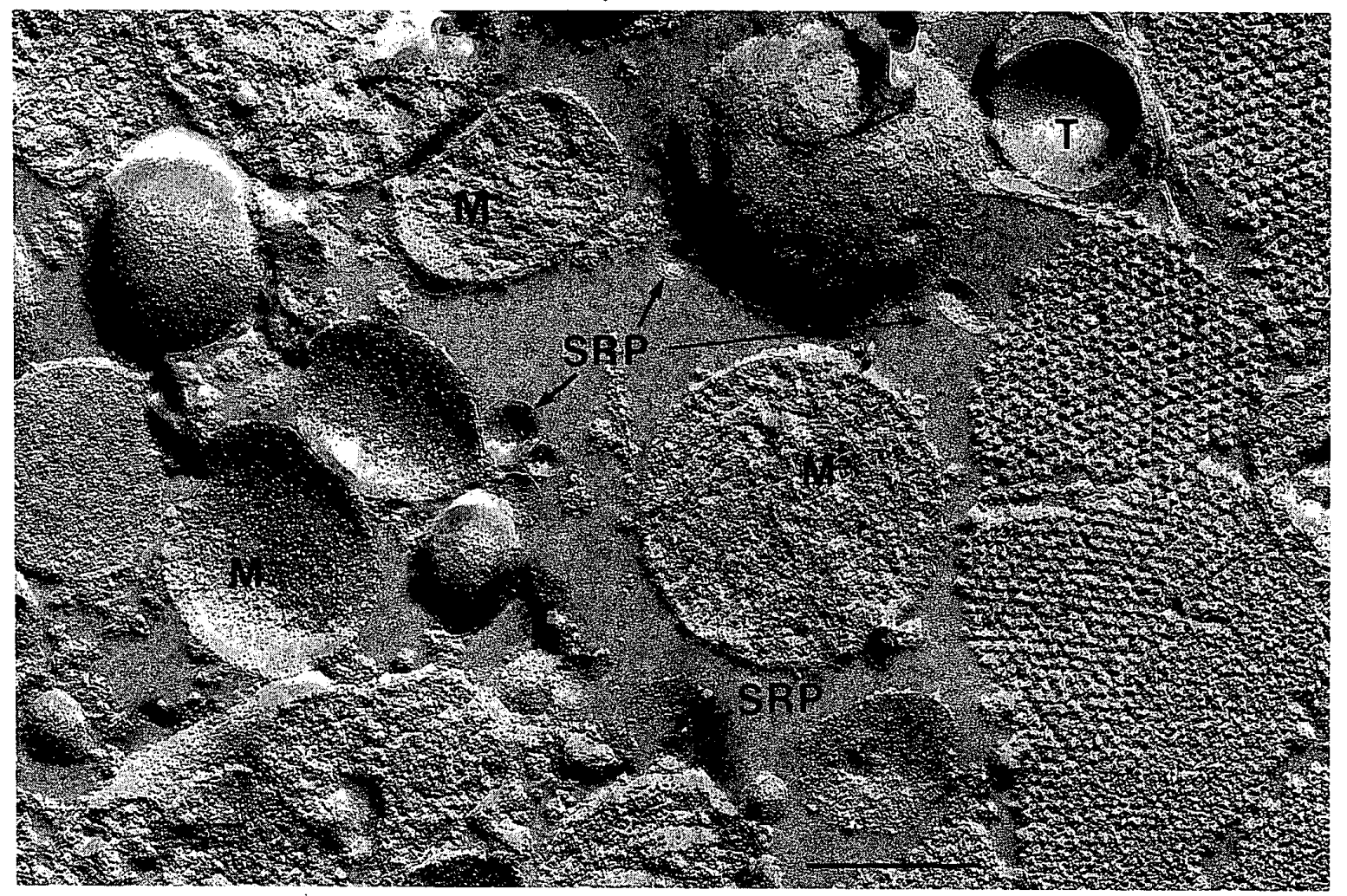

Fig.5. A myocardial cell $120 \mathrm{~min}$ after coronary ligation. Severe intracellular edem is observed and sarcoplasmic reticulum is swollen and vesiculated. Particle density on $\mathbf{P}$ face of sarcoplasmic reticulum (SPR) is significantly reduced. $\mathbf{M}=$ mitochondria. $\mathrm{T}=\mathrm{T}$-system. Bar indicates $0.5 \mu \mathrm{m}$. 


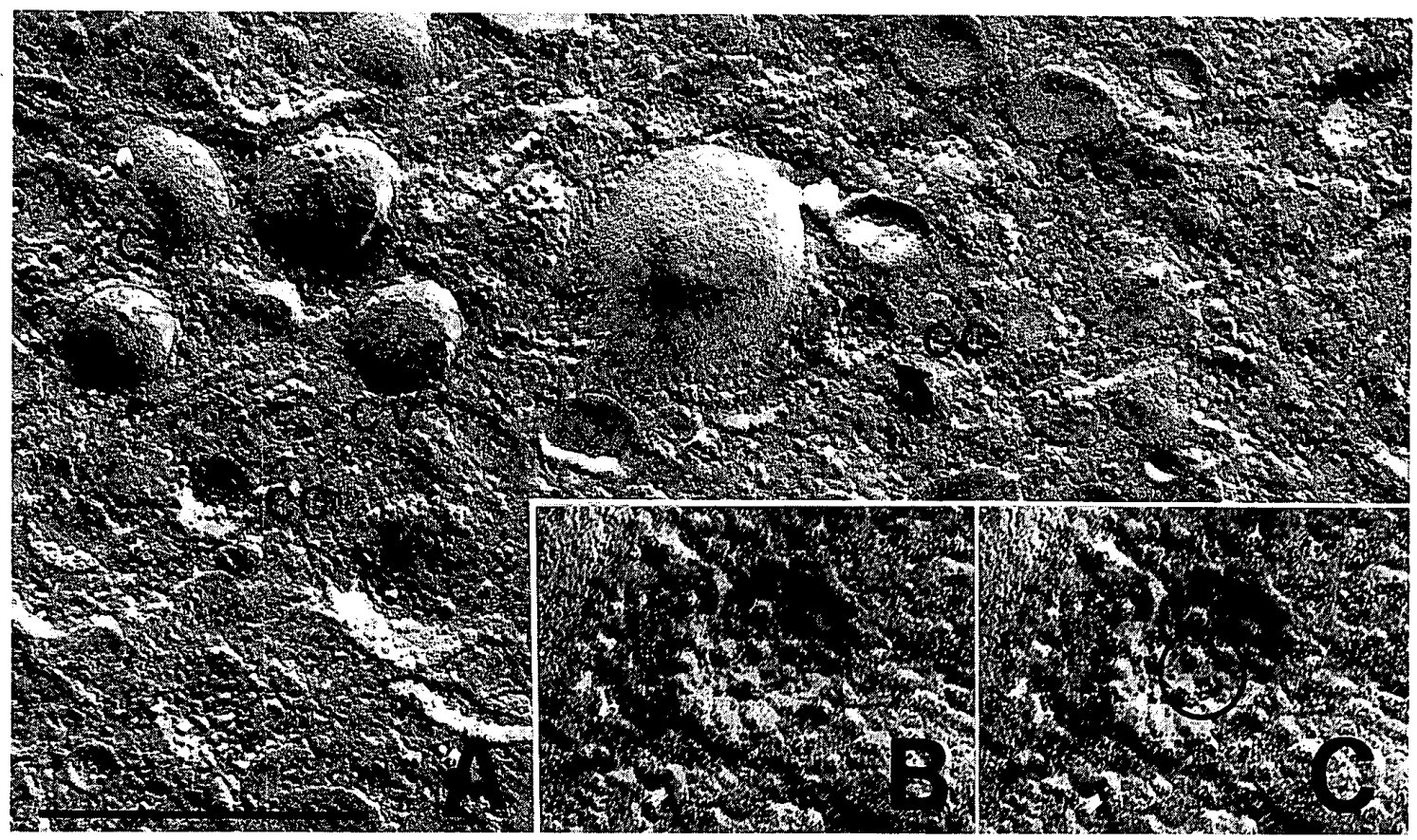

Fig.6. A: Electron micrograph of freeze-fracture replica of isolated SR fractions from non-ischemic heart muscles showing concave (CC) and convex (CV) vesicle profiles with and without (arrow) cast shadow. Bar indicates $0.5 \mu \mathrm{m} . \times 61,500$.

$\mathrm{B}, \mathrm{C}$ : Concave profiles without cast shadow reveal intramembranous particles whose density is counted by applying a test circle. $\times 150,000$.
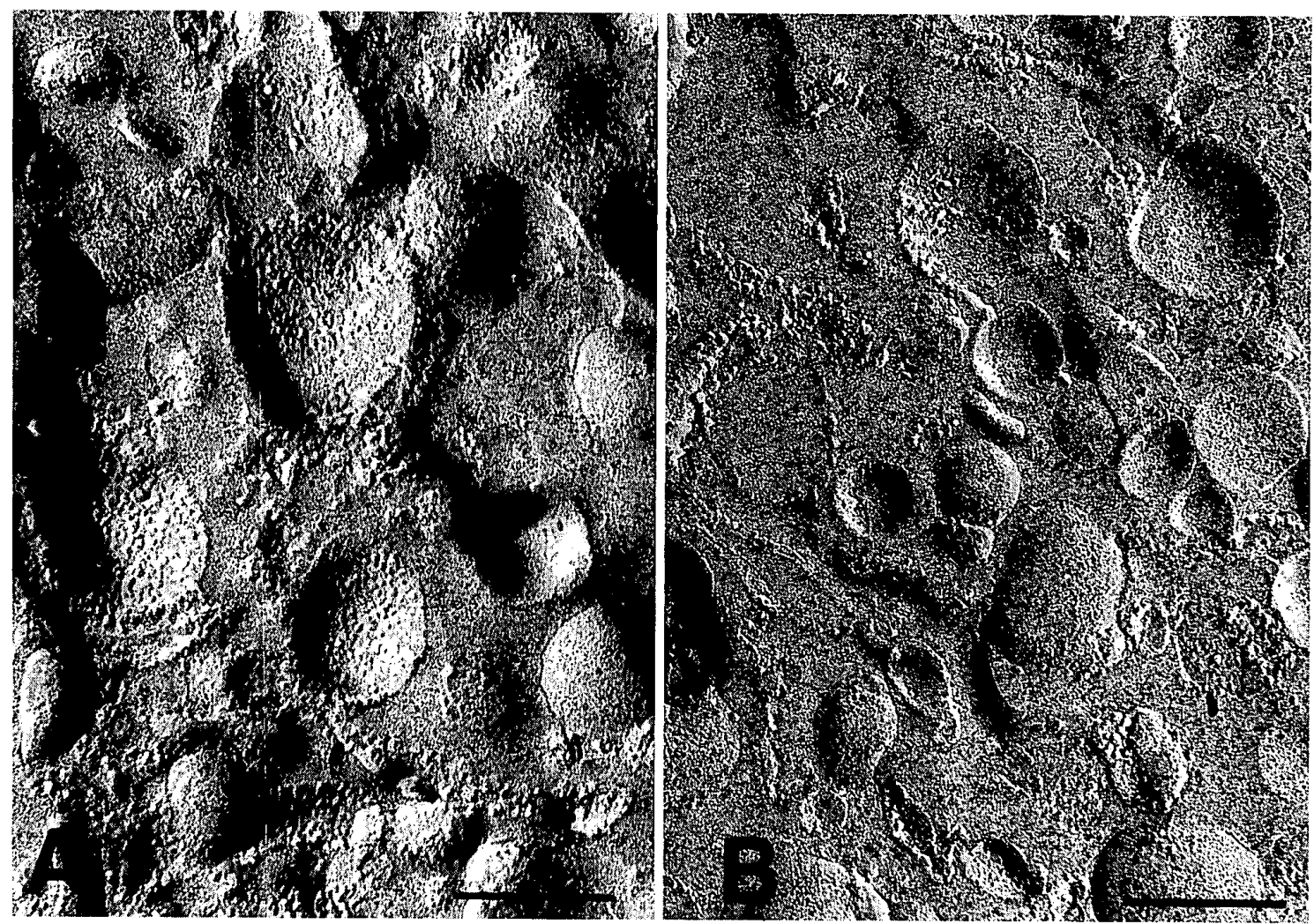

Fig.7. Freeze-fracture replicas of isolated SR fractions from non-ischemic (A) and 60 min ischemic (B) heart muscles. A: Isolated SR from non-ischemic myocardium shows a greater particle density on the outer fracture (concave) face than on the inner fracture (convex) face. Bar indicates $0.2 \mu \mathrm{m}$. B: Number of particles decreases on the concave face of 60 -min-ischemic microsomes. Bar indicates $0.2 \mu \mathrm{m}$. 
TABLE I PARTICLE DENSITY OF FREEZE-FRACTURED SR MEMBRANE

\begin{tabular}{ccc}
\hline \hline & P-face & E-face \\
\hline $\begin{array}{c}\text { SR in situ } \\
\text { Non-ischemic }\end{array}$ & $3,319 \pm 75(100)$ & $591 \pm 55(100)$ \\
& Concave face & Convex face \\
\hline Isolated $S R$ & & \\
Non-ischemic & $2,667 \pm 60(200)$ & $570 \pm 57(200)$ \\
Ischemic & & \\
$30 \mathrm{~min}$ & $1,989 \pm 83(200)$ & $528 \pm 55(200)$ \\
$60 \mathrm{~min}$ & $1,550 \pm 66(200)$ & $389 \pm 40(200)$ \\
$120 \mathrm{~min}$ & $1,506 \pm 65(200)$ & $380 \pm 48(200)$ \\
$180 \mathrm{~min}$ & $1,269 \pm 65(200)$ & $344 \pm 45(200)$ \\
\hline
\end{tabular}

Values are numbers of particles $/ \mu^{2}$, expressed as mean \pm standard error. Numbers in parentheses are the number of vesicles counted.

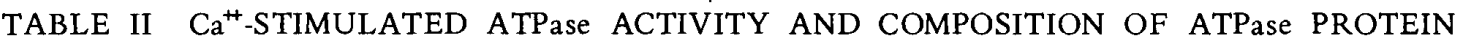

\begin{tabular}{ccc}
\hline \hline & $\begin{array}{c}C^{+*} \text {-stimulated } \\
\text { ATPase activity }\end{array}$ & $\begin{array}{c}\text { Composition of } \\
\text { major ATPase protein }\end{array}$ \\
\hline $\begin{array}{l}\text { Non-ischemic } \\
\text { Ischemic }\end{array}$ & $11.2 \pm 3.3$ & $38.7 \pm 8.0$ \\
$30 \mathrm{~min}$ & $5.7 \pm 1.2^{*}$ & $22.4 \pm 4.9^{* *}$ \\
$60 \mathrm{~min}$ & $6.8 \pm 1.1^{*}$ & $19.7 \pm 7.0^{* *}$ \\
$120 \mathrm{~min}$ & $3.9 \pm 2.2^{*}$ & $13.4 \pm 3.3^{* *}$ \\
$180 \mathrm{~min}$ & $4.1 \pm 0.7^{* *}$ & $13.5 \pm 5.9^{* *}$ \\
\hline
\end{tabular}

ATPase activity is expressed as $\mu$ moles $\mathrm{Pi} / \mathrm{mg} S \mathrm{R}$ protein $/ \mathrm{hr}$ at $37^{\circ} \mathrm{C}$, and composition is shown as per cent. Values are mean \pm standard deviation. $p<0.01 ; * * p<0.005$

the SR and T-tubules became more severe and was accompanied by mitochondrial swelling. In the swollen SR the number of IMP decreased significantly, and this decrease was moderately heterogeneous in each ischemic cell, indicating the heterogeneous ischemic changes as described previously?

Intramembranous particles (IMP) in the isolated SR membrane. Freeze-fracture electron micrographs of the isolated SR membrane exhibited the typical IMP of 70 to $90 \AA$ in diameter in the same manner as seen in the SR membrane in situ, and a greater density of IMP was seen on outer fracture (concave) face than on inner fracture (convex) face of the isolated SR vesicles (Fig. 6, 7). The density of IMP of the isolated SR vesicles from the normal myocardium was $2,667 / \mu \mathrm{m}^{2}$ and was somewhat lower than that of the SR in situ. This difference was not surprising because of (1) alterations of insideoutside membrane relationship, (2) contamination of sarcolemmal fraction, and (3) extraction of membrane-associated proteins in the isolation procedure. The particle densities in the isolated SR are summarized in Table I. The isolated SR vesicles revealed an approximately 5 -fold greater concentration fo IMP at the hydrophobic center of the outer (concave) versus inner (convex) fracture face. In the ischemic myocardium the average densities of IMP on concave face decreased to $1989,1550,1507$ and $1269 / \mu \mathrm{m}^{2}$ at $30,60,120$ and $180 \mathrm{~min}$ after coronary ligation, respectively. Since the protein of the SR membrane consists mainly $(>38 \%)$ of one type of protein, the density of IMP should be directly proportional to the concentration of calcium pump protein of the membrane.

Biochemical studies of the sarcoplasmic

Japanese Circulation Journal Vol. so, September 1986 
$10 \%$ Acrylamide
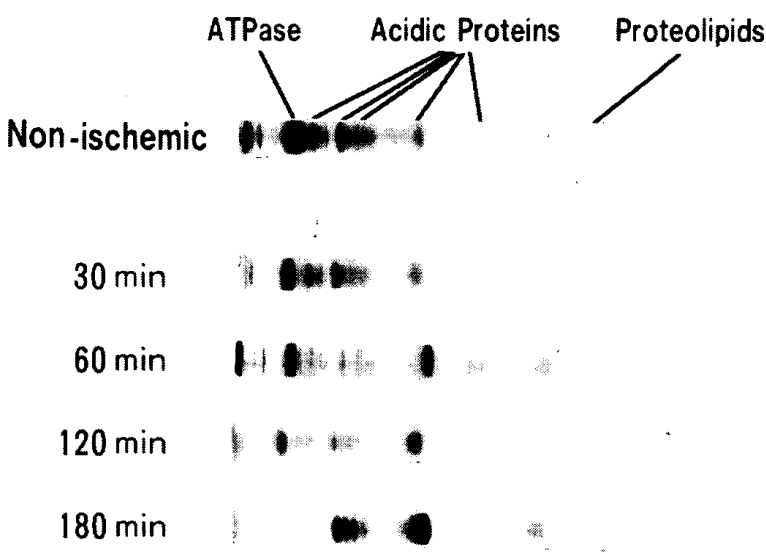

Fig.8. Electrophoresis in $10 \%$ SDS-polyacrylamide gels of isolated $S R$ fractions from non-ischemic and ischemic myocardia. Content of the major ATPase protein band decreases in the course of ischemia.

reticulum. $\mathrm{Ca}^{\text {+⿱}}$-stimulated ATPase activity of the isolated $\mathrm{SR}$ was $11.2 \pm 3.3 \mu$ moles $\mathrm{Pi} / \mathrm{mg}$ protein/hour at $37^{\circ} \mathrm{C}$ in the non-ischemic myocardium and was not significantly different from that of the normal myocardium. In the ischemic myocardium the activity decreased significantly to $5.7 \pm 1.2 \mu$ moles $\mathrm{Pi} / \mathrm{mg}$ protein/hour, $50.9 \%$ of that of the non-ischemic myocardium, at 30 min after coronary ligation. After that slight further reduction was noted up to $180 \mathrm{~min}$ after ligation, as shown in Table II.

Electrophoretic gels of the isolated SR are shown in Fig. 8. SR proteins were composed of a major ATPase protein (100,000 dalton), several acidic proteins $(50,000-70,000)$, and proteolipids $(22,000)$ in the same manner as previously reported. The major ATPase protein occupied about $40 \%$ of the total SR proteins in densitometry. In the ischemic myocardium a significant decrease in the band of the major ATPase was recognized, 22.4, 19.7, 13.4 and $13.5 \%$ in ischemia for $30,60-180 \mathrm{~min}$, respectively, as shown in Table II. The reduction in $\mathrm{Ca}^{+}$-stimulated ATPase activity was roughly parallel with the decrease in the content of the major ATPase protein.

\section{DISCUSSION}

The SR is a highly specialized membrane which is composed mainly of $\mathrm{Ca}^{+}$-pump protein.,7 The presence of particles on freezefracture face of the SR and their possible relationship to the $\mathrm{Ca}^{+}$-pump protein was first pointed out by Deamer and Baskin? The particles observed on freeze-fracture seem to be referable to the $\mathrm{Ca}^{++}$-pump protein or a complex of the $\mathrm{Ca}^{++}$-pump protein with phospholipid! $\mathbf{1 6}$ The SR membranes have a very asymmetric distribution of particles between the $\mathrm{P}$ and $\mathrm{E}$ faces. Rayns et al?, in a study on guinea pig papillary muscles, found a tree-to-one density difference between the $\mathrm{P}$ and $\mathrm{E}$ faces of the SR. In the present study approximately six-to-one asymmetry of particles was observed in the $\mathrm{P}$ to E faces. Also, a similar particle asymmetry was found in the isolated SR vesicles. This means that most of the isolated SR vesicles are right side-ont. The particle densities of the isolated SR vesicles are lower than those of the $S R$ in situ. It is conceivable that contamination of $\mathrm{T}$-system and sarcolemmal vesicles would include concave and convex faces, with a few particles corresponding to the low-density faces of these membranes.

The area of SR membrane being measured by any planimetric method will be underestimated due to the curvature of these structures. The amount of underestimation can be approximated for each area from the geometry of the organelle (vesicle, tube, flat sac, etc). And, as has been described previously, ${ }^{17}$ the number of particles in any given area of membrane fracture face also is underestimated since particles which are small in diameter and lie within the fractured membrane area tend to be lost in the background and not counted. Fortunately, in the SR membrane most of the IMP were relatively large, i.e. 70 to $90 \AA$ in diameter, and easy to count. Therefore, there was very little particle underestimation in this study. In order to correct the underestimation of area we used Weibel's stereological methods.10 Particle densities on the $P$ face of the normal SR were similar to those reported previously, i.e. $1030 / \mu \mathrm{m}^{2}$ in guinea pigs, ${ }^{9} 4938 / \mu \mathrm{m}^{2}$ in dogs 18 and $1609 / \mu \mathrm{m}^{2}$ in dogs?

In the study of conventional thin-section electron microscopy the progressive dilatation of the SR was easily recognized after $30 \mathrm{~min}$ of coronary ligation. Bryant and co-workers 5 noticed that after 1 hour of ischemia enlargement of the SR was prominent, and at 4 hours the SR was remarkably swollen and some vesicles ruptured. Jennings and his co-workers ${ }^{19,20}$ demonstrated in the ischemic dog myocardium that the increased $\mathrm{Ca}$ accumulated at the intramitochondrial dense deposits as a form of calcium phosphate, and postulated that the 
appearance of the deposits was the earliest sign of myocardial irreversibility due to sichemia. In ultrastructural histochemical studies Ozawa et $\mathrm{al}^{21}$ reported a reduction in the ATPase reaction product in the SR $60 \mathrm{~min}$ after coronary ligation, with simultaneous swelling of the terminal cisternae of the SR and the appearance of mitochondrial dense deposits. In the ischemic myocardium, changes in the SR membrane have not been studied rigorously by freeze-fracture techniques. Imai et $\mathrm{al}^{3}$ found that the number of IMP of the SR was reduced by up to $50 \%$ in ischemia for $60 \mathrm{~min}$, and postulated that the reduced number of IMP in the ischemic zone might be an indication of their inability to transport $\mathrm{Ca}^{++}$or to remove $\mathrm{Ca}^{+}$from the cytoplasm.

The decrease in particle density of the SR membrane under ischemia is also conceivable. However, in the present study the SR was isolated in the same condition in both the nonischemic and ischemic heart muscles; therefore, swelling of the SR in situ in the ischemic state should be negligible on particle density of the isolated $S R$ vesicles.

In biochemical studies Schwartz et al2 found a defect in SR calcium release after $12-60 \mathrm{~min}$ of ischemia. A reduction in $\mathrm{Ca}^{+1}$-uptake of cardiac SR was recognized by Lee et $\mathrm{al}^{22}$ and Hess et $\mathrm{al}^{23}$ within $60 \mathrm{~min}$ and $30 \mathrm{~min}$ of ischemia, respectively. Toba et al! also observed reductions in $\mathrm{Ca}^{+}$-stimulated ATPase activity and $\mathrm{Ca}^{+1}$-uptake rate in parallel with a decrease in the content of ATPase protein, and concluded that the impairment of SR activities in myocardial ischemia contributed to the degradation of ATPase protein itself. In agreement with these morphologic and biochemical studies, a decrease in the density of particles with progressive swelling of the SR and corresponding changes in the biochemical data were noted after 30-60 min of ischemia, and these indicate the degradation of ATPase protein.

Hoffstein et al ${ }^{24}$ reported that acid hydrolases were located not only in lysosomes but also in the SR with cytochemical method and attributed the latter to the degradation of the ischemic myocardium. Recently, Sasai et al. ${ }^{25}$ observed the activation of hydrolases such as acid phosphatase, $\beta$-glucuronidase and cathepsin $\mathrm{D}$ of the SR in the early stage of myocardial ischemia. Increases in the size, number and enzymatic activity of acid phosphatase in lysosomes and SR were also observed within 15 min of coronary ligation. ${ }^{26}$ The activation of acid hydrolases in the SR should be the presipitating factor for the degradation of the SR in the acidic state in the ischemic myocardium. In this study, impaired cardiac SR was observed in ischemia for 30 to $60 \mathrm{~min}$ as the degradation of its intramembranous particles, which should be the ATPase protein intself; these changes of the SR are an indication of irreversible myocardial injury.

\section{Acknowledgments}

The authors wish to express sincere thanks to Professor Hirokazu Niitani and Professor Yasumitsu Nakai of Showa University for their kind guidance and encouragement. We are also greatly indebred to Drs. Sumiyasu Sekita, Hitoshi Kanaya and Youich Takeyama for their kind collaboration and to Eriko Iijima for technical assistance.

\section{REFERENCE}

1. TOBA K, KATAGIRI T, TAKEYAMA Y: Studies on the cardiac sarcoplasmic reticulum in myocardial infarction. Jpn Circ J 42: 447, 1978

2. SCHWARTZ A, WOOD JM, ALLEN JC, BORNET EP, ENTMAN ML, GOLDSTEIN MA, SORDAHL LA, SUZUKI M, LEWIS RM: Biochemical and morphologic correlates of cardiac ischemia. 1 . membrane systems. Am J Cardiol 32: 46, 1973

3. IMAI K, WANG T, MILLARD RW, ACHRAF M, KRANIAS ES, ASANO G, DEGENDE AOG, NAGAO T, SOLARO RJ, SCHWARTZ A: Ischemiainduced changes in canine cardiac sarcoplasmic reticulum. Cardiovasc Res 17: 696, 1983

4. DENKER MW, BERGMAN RA, NACHLAS MM: Ultrastructural changes in myocardium during experimental ischemia. Johns Hopkins Med J 124: 311,1969

5. BRYANT RE, THOMAS WA, O'NEAL RM: An electron microscopic study of myocardial ischemia in the rat. Circ Res 6: 699, 1958

6. MACLENNAN DH, SEEMAN GHIP, YIP CC: Membrane formation by the adenosine triphosphatase of sarcoplasmic reticulum. J Biol Chem 246: 2702, 1971

7. TADA $M$, YAMAMOTO $T$, TONOMURA Y: Molecular mechanismus of active calcium transport by sarcoplasmic reticulum. Physiol Rev 58: 1, 1978

8. DEAMER DW, BASKIN RJ: Ultrastructure of sarcoplasmic reticulum preparations. $J$ Cell Biol 42: 296, 1969

9. RAYNS DG, DEVINE CE, SUTHERLAND CL: Freeze fracture studies of membrane systems in vertebrate muscle. 1. Striated muscle. J Ultrastruct Res 50: 306, 1975

10. WEIBEL ER, LOSA G, BOLENDER RP: Stereological method for estimating relative membrane surface area in freeze-fracture preparations of subcellular fractions. J Microsc 107: 255, 1976

11. HARIGAYA S, SCHWARTZ A: Rate of calcium binding and uptake in normal animal and failing human cardiac muscle. Circ Res 25: 781, 1969 
12. HARIGAYA S, OGAWA Y, SUGITA M: Calcium binding activity of microsomal fraction of rabbit red muscle. J Biochem 63: 324, 1968

13. FISKE CH, SUBBAROW Y: The colorimetric determination of phosphorus. J Biol Chem 66: 375,1925

14. WEBER $\mathrm{K}$, OSBORN M: The reliability of molecular weight determinations by dodecyl sulfate polyacrylamide gel electrophoresis. J Biol Chem 244: 4406, 1969

15. SOMMER JR, JOHNSON EA: Ultrastructure of cardiac muscle. In Handbook of physiology, vol 1 sec 2 chap 5, ed by BEME R, SPERELKIS N, American Physiological Society, Washington DC, 1979, p 113

16. WANG CT, SAITO A, FLEISCHER S: Correlation of ultrastructure of reconstituted sarcoplasmic reticulum membrane vesicles with variation in phospholipid to protein ratio. J Biol Chem 254: 9209, 1979

17. CROWE LM, BASKIN RJ: Freeze-fracture of intact sarcotubular membranes. J Ultrastruct Res 62: 147,1978

18. FRANK JS, PHILIPSON KD, BEYDLER $\mathrm{S}$ : Ultrastructure of isolated sarcolemma from dog and rabbit myocardium. Comparison to intact tissue. Circ Res 54: 414, 1984

19. SHEN AC, JENNINGS RB: Myocardial calcium and magnesium in acute ischemic injury. $A m J$
Pathol 67: 417, 1972

20. SHEN AC, JENNINGS RB: Kinetics of calcium accumulation in acute myocardial ischemic injury. Am J Pathol 67: 441, 1972

21. OZAWA K, TAKEYAMA Y, KATAGIRI T: Electron microscopic studies on the ATPase activity in myocardial infarction. Jpn Circ J 46: 725, 1982

22. LEE KS, LADINSKY $H$, STUCKEY JH: Decreased $\mathrm{Ca}^{++}$-uptake by sarcoplasmic reticulum after coronary artery occlusion for 60 and 90 minutes. Circ Res 21: 439, 1967

23. KRAUSE S, HESS ML: Characterization of cardiac sarcoplasmic reticulum dysfunction during short-term, normothermic, global ischemia. Circ Res 55: 176, 1984

24. HOFFSTEIN S, GENNARO DE, WEISSMANN G, HIRSCH J, STREULI F, FOX AC: Cytochemical localization of lysosomal enzyme activity in normal and ischemic dog myocardium. Am $J$ Pathol 79: 193, 1975

25. SASAI $\mathrm{Y}$, NAKAMURA $\mathrm{N}$, KOBAYASHI $\mathrm{Y}$, KATAGIRI T: Studies on intracardiac acid hydrolases in the ischemic myocardial necrosis. Jpn Circ J 46: 1337, 1982

26. NAKAMURA $\mathrm{N}$, SASAI $\mathrm{Y}$, TAKEYAMA $\mathrm{Y}$, KATAGIRI T: Electron microscopic cytochemical studies on acid phosphatase activity in acute myocardial ischemia. Jpn Heart J 24: 595, 1983 